14. Колесникова И.А. Открытое образование: перспективы, вызовы, риски // Высшее образование в России. 2009. № 7. С. 12-23.

15. Беляева М.А. Риск как предмет научного анализа в педагогике и образовании // Педагогическое образование в России. 2014. № 11. С. 16-23.

16. Останин В.А., Рожков Ю.В. «Шанс-менеджмент» и «риск-менеджмент» как диалектические противоположности теории управления // Вестник ХГАЭП. 2014. № 6. С. 4-7.

17. Сабинина Н.Н. Риски в инновационной деятельности педагога и их профилактика // Мир науки, культуры, образования. 2011. № 6. С. 85-89.
18. Султанова Т.А. Образовательная ситуация как объект прогнозирования развития школы // Вестник Оренбургского государственного университета. 2015. № 1. С. 66-70.

19. Султанова Т.А. Прогностические аспекты деятельности школы по профилактике аддиктивного поведения учащихся // Молодой ученый. 2014. № 4. C. 1111-1114.

20. Султанова Т.А. Прогнозирование деятельности образовательного учреждения по профилактике аддиктивного поведения школьников // Образование и общество. 2014. № 3. С. 65-68.

\title{
RISKS AND CHANCES PREDICTION OF SCHOOL INNOVATIVE DEVELOPMENT: SUBSTANTIVE AND METHODOLOGICAL ASPECTS
}

(C) 2016

T.A. Sultanova, candidate of pedagogical sciences, associate professor of the Chair of General and Professional Pedagogy

Orenburg State University, Orenburg (Russia)

Abstract. The problem of school innovative educational activities is considered to be urgent due to the competition on the market of educational services. Content, technology and teaching educational innovations become the source of competitive advantages of the modern school. Innovation is always a risk, because only a few of them are implemented in reality and lead to positive results. The purpose of this paper is to clarify the content and methodological aspects of opportunities and risks prediction as an integral part of school innovative development. The basis of the author's position is the probabilistic nature of school, which is manifested in the uncertainty and unpredictability of the effects of innovations introduction in the educational process. Subjects of innovative activity, innovative activity itself and the environment are thought to be the main factors of uncertainty. Chances and risks are considered to be the forms of actualization of school future development. Chances and risks are objective and subjective. The author describes a hierarchy of predictable chances and risks, including operational, tactical and strategic levels. Chances and risks prediction is considered to be a mechanism for reducing the uncertainty and unpredictability of school innovative development. The author represents methodological aspects of opportunities and risks prediction. The paper contains an example of real educational practice.

Keywords: innovation; innovative development of the school; probabilistic nature; chances; risks; uncertainty about the future; factors of uncertain future; state of uncertainty; educational prediction; alternative solutions; method of chances and risks prediction.

УДК 372.881.111.1

\section{МЕТОД КВЕСТ КАК ИННОВАЦИОННАЯ ФОРМА ОБУЧЕНИЯ АНГЛИЙСКОМУ ЯЗЫКУ ДЕТЕЙ ДОШКОЛЬНОГО ВОЗРАСТА} (C) 2016

И.В. Ткач, магистрант кафедры теории и практики иностранных языков и лингводидактики О.А. Минеева, кандидат педагогических наук, доцент кафедры иноязычной профессиональной коммуникации Нижегородский государственный педагогический университет им. К. Минина, Нижний Новгород (Россия)

Аннотация. В статье рассматривается метод квест как инновационный метод обучения английскому языку детей дошкольного возраста. Описываются задачи и принципы раннего обучения, психологические особенности готовности детей к изучению иностранного языка и вклад занятий по изучению иностранного языка в общее развитие ребенка. В работе рассмотрены игровые методы обучения, а также факторы, определяющие успех использования игр на занятиях для детей дошкольного возраста. Дано определение понятию «квест», определена возможность использования этого метода в качестве одного из игровых методов в обучении английскому языку. В технологию использования квеста включены современные аудио-визуальные материалы, задания на аудирование, говорение, чтение, узнавание изученного лексического материала. Помимо заданий, направленных непосредственно на изучение иностранного языка, в квесте содержатся задания на развитие логического мышления, внимательности, развитие моторики при создании аппликации. Рассмотрен практический опыт применения данного метода при изучении темы «Еда» в группе дошкольников: описаны общая концепция квеста, задания, необходимый реквизит. Описанный метод обучения иностранному языку может быть адаптирован как любому возрасту учащихся, так и к любому учебному предмету.

Ключевые слова: раннее обучение английскому языку; игровые методы в обучении; инновационный метод обучения; квест; метод квест; дошкольное обучение; занятия с дошкольниками; обучение английскому языку; обучение дошкольников английскому языку; обучение через игру; общее развитие дошкольников. 
Раннее обучение и развитие детей - актуальная тенденция в воспитании: с самого раннего возраста дети занимаются в спортивных секциях, музыкальных школах, центрах творчества. Изучение иностранных языков отличается особенно высоким спросом на рынке образовательных услуг, в частности, изучение английского языка. В педагогике накоплен значительный опыт в обучении дошкольников иностранному языку [1-4]. Вопросами раннего обучения занимались ученые А.А. Леонтьев, Е.Ю. Протасова, H.М. Родина и другие, но данный вопрос не теряет своей актуальности, поскольку различные методики обучения оставляют пространство для научных исследований [5-8].

Раннее обучение иностранным языкам ставит своей главной целью формирование у учеников коммуникативной компетенции [9, с. 114]. Раннее обучение во многом схоже с развивающим обучением и основывается на принципах развития: культуросообразности - процесс усвоение нравственных норм и общекультурных ценностей, необходимых для взаимодействия с представителями других стран; принцип общения, которое рассматривается как средство усвоения ценностей; природосообразности - учет когнитивных и психофизиологических особенностей при обучении; и самостоятельности - способности получать знания в процессе учебной и творческой деятельности [10, с. 8-14].

Раннее обучение иностранным языкам призвано помочь общему развитию ребенка, основываясь на психологических и физиологических особенностях дошкольников [11-13]. В литературе выделяются особенности, присущие младшим школьникам и детям дошкольного возраста. К ним относятся преобладание наглядно-образного мышления, непроизвольные процессы в восприятии и запоминании информации. Детям данного возраста присуще буквальное запоминание, зависящее от образности, яркости и личной вовлеченности ребенка в процесс познания. По словам М.И. Еникеева существуют несколько факторов непроизвольного запоминания информации сильные и значимые физические раздражители, смена действия, раздражители, значимые для личности, раздражители, имеющие эмоциональную окраску, деятельность, которая непосредственно связана с потребностями индивида. Все эти факторы необходимо использовать на занятиях с дошкольниками для достижения наилучших результатов [14].

К началу изучения иностранного языка ребенок должен быть достаточно развит, этот период определяется не возрастом дошкольника, а его психологическими и физиологическими особенностями. Наиболее благоприятным периодом для начала изучения языка считается период 6-7 лет, но некоторые малыши более младшего возраста также готовы начать изучение языков. Этот возраст считается наиболее сенситивным, когда дети наиболее чувствительны к языковым явлениям, и могут неосознанно осваивать большие объемы информации.

Но что может мотивировать ребенка 5-7 лет к изучению иностранного языка? Ответ на этот вопрос учеными уже найден - это игра. Игровые методы широко используются в обучении дошкольников, и позволяют реализовать все принципы раннего обучения, а также учесть психологические особенности дошкольников [15-18]. Процесс обучения через игры это обучение без сознательной затраты сил и времени, это обучение с удовольствием, которое задействует эмоции, развивает воображение и мышление. Использование иностранного языка в играх позволяет перейти на новый для дошкольника язык, оправдывая это «правилами» игры.

А.П. Василевич, говорит о том, что недостатки первого года обучения, могут быть скорректированы позднее, а отсутствие мотивации и упорное нежелание изучать язык преодолеть достаточно сложно [19, c. 75]. Игра отвечает всем требованиям раннего обучения, позволяет учитывать в процессе обучения психологические и физические особенности детей, мотивировать детей на изучение языка.

В современном образовании существует множество игровых методов, позволяющих сделать процесс изучения английского языка увлекательным и интересным для дошкольников. В арсенале педагогических средств различные игровые учебно-методические пособия, интерактивная поддержка в виде аудиовизуальных средств, карточек с картинками, а также компьютерных игр, способствующих обучению детей английскому языку, а также развитию - логического мышления, самостоятельности, скорости реакции. Но в наш чрезмерно компьютерный век, нам необходимо вернуться к тому, чему не может обучить ни один компьютер - живому общению, формированию коммуникативной компетенции и готовности к построению коммуникации с представителями других языков и культур.

Одним из инновационных форм обучения дошкольников является квест. Термин «квест» становится известным с 70-х годов прошлого века, когда он заимствуется разработчиками компьютерных игр из литературы в жанре фэнтези. Квест - «quest» с английского языка переводится как «поиск, предмет поиска, поиск приключений». Изначально под квестом понималось приключение с множеством испытаний и трудностей, которые необходимо преодолеть для достижения цели, одним из ярких примеров является миф о 12 подвигах Геракла. Таким образом, в квесте должны присутствовать главные герои, цель поиска или приключения, дополнительные персонажи, помогающие или мешающие героям, задания, в которых нужно проявить не только физическую силу, но и логическое мышление [20, с. 14].

Квест позволяет наполнить игру множеством интересных и познавательных заданий, позволяющих участникам игры не только выполнять задания, но и укрепить командный дух в детском коллективе, создать ситуацию успеха, и сгладить соревновательные моменты между детьми [21-22].

В рамках нашего исследования метод квест как метод обучения английскому языку использовался в группе дошкольников 6-7 лет. В данном возрасте одна из наиболее интересных тем - это пиратские приключения с поиском сокровищ.

Завязка:

Детям рассказывается легенда, в которой существуют 2 пирата - хороший и плохой. По легенде один из пиратов спрятал сокровища от ребят и зашифровал карту, и только те, кто сможет разгадать 
все загадки пирата, вернет сокровища. Образ второго, злого пирата является абстрактным, лично дети с ним не встречаются.

Реквизит игры: карта сокровищ с зашифрованными подсказками.

Команда движется в соответствии с заданиями в записках, в которых зашифровано то место, в котором их ждут задания. Команду сопровождает пират, принимающий на себя обязанности консультантаигротехника, готового дать подсказку или повести ситуацию в игре в нужном направлении. Квест объединен единой темой, в рамках которой изучаются лексические единицы.

Рассмотрим пример использования метода квест с целью изучения лексических единиц по теме «Еда».

Первый этап: В помещении обязательно должен быть телевизор, проектор или другой экран для демонстрации видео. На видном месте находится пульт. На первом этапе детям выдаются картинки с различными предметами еды (такой, какую обычно любят дети, например, пицца, курица, картофель фри, молочный коктейль, сок, мороженое и пульт).

Пират спрашивает детей, что это и выясняет, в наборе есть лишняя карточка - карточка с пультом, наводит детей на мысль о пульте. Дети используют пульт и запускают видео с песней/ видео словарем по теме еда. Смотрят два раза, после чего Пиратигротехник проводит игру на распознавание и повторение слов.

Второй этап: Дети движутся соответственно по карте к следующему этапу. На данном этапе предлагается собрать паззл из трех частей, содержащих в себе картинку и слово. В комнате расположены «плакаты » со словами с одной пропущенной буквой и недостающей картинкой, задачей команды является добавить букву (буквы прилагаются) и добавить (приклеить) картинку к слову. Дети читают слова, при необходимости прибегая к помощи инструктора Пирата.

Третий этап: Ребята смотрят видео, в котором Пират, спрятавший клад, рассказывает о своей любимой еде и предлагает детям приготовить для него чтонибудь. В реквизите имеются заготовки из цветной бумаги, из которых можно составить (склеить, собрать) элементы еды, изученные на занятии, и сделать аппликацию на заготовке тарелки, имеющейся у каждого ребенка. В конце рассказать об этом свои товарищам по команде и Пирату, если ребята справились с заданием (а они должны справиться при помощи хорошего Пирата). Включается видео со вторым «злым» пират, который хвалит детские «блюда» и дает последнее задание - расставить карточки с картинками и словами в алфавитном порядке и назвать их. Когда задание выполнено, дети получают подсказку, где можно найти ключ от сундука, внутри которого находятся дипломы, сладкие подарки и словарь с картинками с изученными словами.

Кроме того, метод квест использовался при изучении следующих тем: «Дом», «Животные», «Семья», «Игрушки».

Применение данного метода в процессе обучения английскому языку детей дошкольного возраста позволяет нам сделать вывод о том, что квест является инновационным приемом среди игровых методов обучения, который еще не получил широкого развития в дошкольных образовательных программах, несмотря на факторы, определяющие данный метод, как успешный в раннем обучении: сюжетная игра с определенной целью, для достижения которой необходимо принять правила игры, и выстраивать иноязычную коммуникацию. Выполнение заданий способствуют развитию навыков аудирования и чтения на иностранном языке, поиск решений проблемных ситуаций активизирует логическое и творческое мышления дошкольника, способствуя его всестороннему развитию.

\section{СПИСОК ЛИТЕРАТУРЫ:}

1. Спиридонова А.В. Обучение детей раннего возраста иностранному языку в процессе дополнительного образования: дис. ... канд. пед. наук. Челябинск, 2010. $201 \mathrm{c}$.

2. Протасова Е.Ю., Родина Н.М. Методика обучения дошкольников иностранному языку: учеб. пос. для студентов вузов, обучающихся по специальности «Иностранный язык». М.: ВЛАДОС, 2010. 210 с.

3. Щукин А.Н. Обучение иностранным языкам: Теория и практика: учебное пособие для преподавателей и студентов. 2-е изд., испр. и доп. М.: Филоматис, $2006.480 \mathrm{c}$.

4. Шишкова И.А., Вербовская М.Е. Английский для малышей. Книга для родителей и преподавателей / под ред. Н.А. Бонк. М.: Росмэн, 2006. 157 с.

5. Сальникова Е.С. Обучение дошкольников английскому языку // Science Time. 2015. № 6 (18). C. 446-451.

6. Задорожная Ю.И. Основные теоретические положения реализации духовно-нравственного воспитания дошкольников на занятиях по иностранному языку // Ученые записки. Электронный научный журнал Курского государственного университета. 2015. № 1 (33). С. 205-210.

7. Дворягина Л.А. Развитие детской лингвистической одаренности в дошкольном возрасте // Образование личности. 2014. № 3. С. 100-103.

8. Нечаев Н.Н., Коряковцева О.В. Обучение иностранному языку детей дошкольного возраста // Вестник Московского государственного лингвистического университета. 2012. № 15 (648). С. 23-35.

9. Васильева С.С., Ларионова Л.С., Веденькина М.В. Развитие коммуникативной компетентности у детей дошкольного возраста в процессе обучения английскому языку // Гуманитарные исследования. 2015. № 3 (55). С. 113-119.

10. Никитенко 3.Н. Начинаем изучать английский язык: кн. для учителя к учеб. пособию. 2-е изд. М.: Просвещение, 2013. 353 с.

11. Галанов А.С. Психическое и физическое развитие ребёнка от 3 до 5 лет: Пособие для работников дошкольных образовательных учреждений и родителей. 3-е изд., испр. и доп. М.: АРКТИ, 2006. 96 с.

12. Березина О.В. Особенности обучения иностранному языку детей старшего дошкольного возраста (психолого-педагогический аспект) // Современные тенденции в обучении иностранным языкам и межкультурной коммуникации: Материалы Международной заочной научно-практической конференции. Электросталь: Новый гуманитарный институт, 2011. C. $125-129$. 
Ткач И.В., Минеева О.А.

Метод квест как инновационная форма обучения английскому языку..

13. Садырбаева Ж.Ж. Психологические особенности обучения английскому языку как иностранному детей дошкольного возраста // Иностранные языки: лингвистические и методические аспекты. 2014. № 27. C. 58-60.

14. Еникеев М.И. Общая и социальная психология: учебник для вузов. М.: Издательская группа НОРМА-ИНФРА-М, 1999. 624 с.

15. Конышева А.В. Современные методы обучения английскому языку. Изд. 2-е, стереотип. Мн.: ТетраСистемс, 2004. $176 \mathrm{c}$.

16. Землянская А.А., Яковлева Л.А. Ролевая игра как источник мотивации дошкольников при обучении английскому языку // Международный студенческий научный вестник. 2016. № 5-2. С. 203-204.

17. Евдокимова М.Н., Фоминых М.В. Игра как ведущий метод обучения дошкольников английскому языку // Молодой ученый. 2014. № 5-2 (64). С. 11.

18. Маслиева Е.С. Специфика организации контроля младших школьников по иностранному языку в игровой форме // Проблемы современного педагогического образования. 2015. № 47-1. С. 159-164.

19. Василевич А.П. Учим детей английскому языку // Иностранные языки в школе. 2009. № 4. С. 75-80.

20. Алексеева Н.Д. Квест-экскурсия как инновационная форма экскурсионной деятельности // Вектор науки ТГУ. Серия: педагогика, психология. 2015. № 1. C. 14-17.

21. Рублёва Е.В. Новые образовательные тренды в обучении языкам // Вестник Центра международного образования Московского государственного университета. Филология. Культурология. Педагогика. Методика. 2014. № 1. С. 124-130.

22. Размыслова Л.И. Квест-ориентирование как эффективная форма воспитания при обучении английскому языку // Психология и педагогика XXI века: теория, практика и перспективы материалы III Международной научно-практической конференции. 2015. C. $132-139$.

\section{QUEST AS AN INNOVATIVE METHOD OF TEACHING ENGLISH TO PRESCHOOLERS} (C) 2016

I.V. Tkach, master student of the Chair of Theory and Practice of Foreign Languages and Lingvodidactics

O.A. Mineeva, candidate of pedagogical sciences, associate professor of the Chair of Foreign Language Professional Communication Minin Nizhny Novgorod State Pedagogical University, Nizhny Novgorod (Russia)

Abstract. The paper deals with the method «quest» as an innovative method of teaching English to preschoolers. The authors describe objectives and principles of early learning, psychological characteristics of children's readiness to learn a foreign language and the contribution of learning a foreign language in the overall development of a child. The article discusses methods of game techniques, as well as the factors that determine the success of using games in the classroom for children of preschool age. The definition of «quest» is given in the paper, the possibility to use this method as one of gaming techniques in teaching English is described. The content of the quest includes modern audiovisual materials, tasks for listening, speaking, reading, recognition of the vocabulary. In addition to assignments aimed at learning a foreign language, the quest contains tasks for development of logical thinking, attention, motor development when creating an application. Practical application of this method for the study of the topic «Food» in the group of preschool students is considered: the overall concept of the quest, tasks, necessary props are described. The described method of learning a foreign language can be adapted to any age students and for any school subject.

Keywords: early English language learning; games learning methods; innovative teaching method; the quest; quest method; preschools; classes for preschool children; English language training; teaching English to preschoolers; learning through playing; the overall development of preschoolers. 